\title{
AN UNUSUAL CASE OF NEONATAL URAEMIA
}

BY

\author{
W. A. B. CAMPBELL and JOAN S. DALES \\ From the Royal Belfast Hospital for Sick Children
}

(RECEIVED FOR PUBLICATION MAY 27, 1952)

Uraemia, generally extra-renal in origin, is not uncommon in infancy, but comparatively few cases occur in the neonatal period. The following case of extreme uraemia occurring in an infant dying on the eighth day of life is of interest not only on account of the early manifestation of the uraemia, but on account of its degree and the difficulty. which has been experienced in establishing the cause.

\section{Case Report}

J.B., a boy, was born at home on October 18, 1951, and admitted to the county hospital on October 20 with a history of vomiting and cyanotic attacks, the latter made worse by swallowing. The confinement was apparently normal but no details are, unfortunately, available. Birth weight was 'about $6 \mathrm{lb}$.'. The infant did not improve in the county hospital and on October 22 was transferred to the Royal Belfast Hospital for Sick Children with a tentative diagnosis of congenital heart disease and possibly some oesophageal anomaly as well.

On admission, the general appearance of the infant aroused immediate comment. He lay in the cot, immobile, with the limbs flexed at the knees, hips and elbows (Fig. 1); only a few degrees of movement were

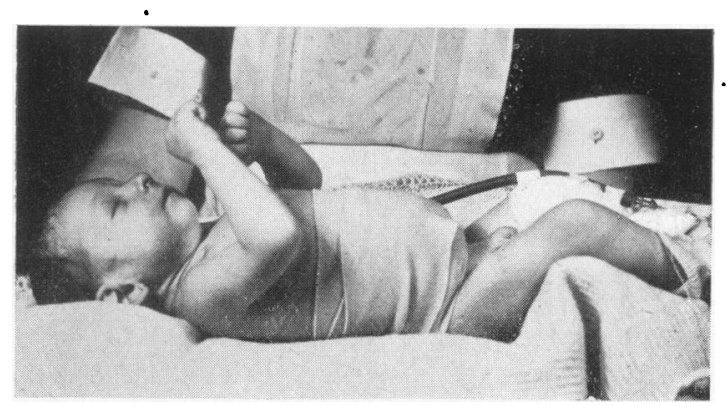

FIG. 1.-J. B. showing flexion deformity of limbs.

possible at any of these joints. The face was smooth with little expression, and rather resembled that of an old man. The eyes were widely set with small epicanthic folds, the nose large and hooked with gaping nostrils, and the ears large and flabby, set low in the head (Figs. 2 and 3). The chest was barrel-shaped with poor
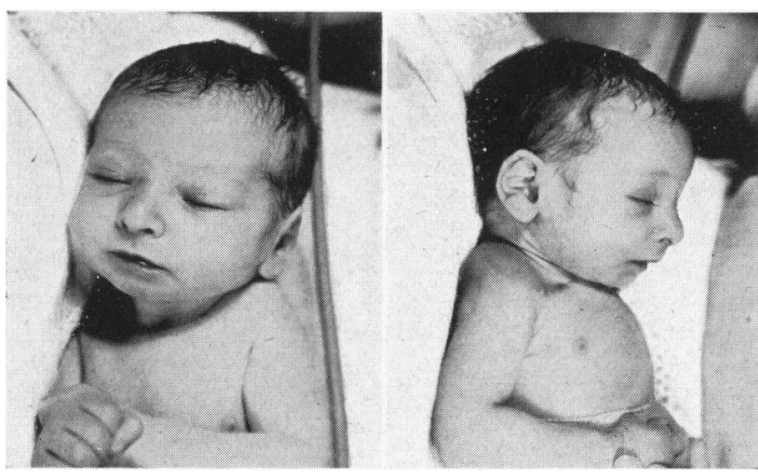

Figs. 2 and 3.-J. B. showing facies.

excursion, and a definite increase in the antero-posterior diameter. The skin of the limbs, and to a lesser extent of the trunk, was thickened, could not be lifted in the fingers, and gave the limbs a curious feel as of 'cold chicken'.

The child's general condition on admission was poor with cyanosis and respiratory distress and slight depression of the fontanelle. There were crepitations in both lungs, most marked at the left base. The heart sounds were very faint, but appeared to be otherwise normal with no murmur. No abnormality was detected in the abdomen, which was soft.

In view of the history of vomiting and cyanosis, the infant was examined under the x-ray screen; a catheter passed into the oesophagus entered the stomach with ease, and when a small amount of lipiodol was allowed to flow into the oesophagus, none passed into the lung fields, thus ruling out any anomaly of the oesophagus. There was no evidence of consolidation or of atelectasis in the lung fields. The upper dorsal vertebrae were more clearly seen than in the average case, and the possibility of an abnormality of the great vessels was considered.

The rectal temperature on admission was $96^{\circ} \mathrm{F}$. and the clinical picture that of sclerema. The facies, however, also suggested the possibility of some congenital abnormality of the kidneys, since the infant bore a marked resemblance to those cases of renal agenesis described by Potter (1946).

The child was placed in an oxygen tent and warmed 
gently. A slow intravenous infusion of half-strength Hartmann's solution in 5\% dextrose was started, and allowed to run at the rate of $400 \mathrm{ml}$. per day. In addition he was given a $1 \mathrm{oz}$. feed three-hourly, containing 'ideal milk', 2 drachms, water, 6 drachms, and $\frac{1}{2}$ drachm glucose; he took the feed with difficulty. Streptomycin and penicillin were given by injection as a precaution against infection.

He had frequent cyanotic attacks despite the oxygen and vomited darkish brown material occasionally. The bowels moved twice or three times daily, the stools being dark and semi-formed. It was noted that even when hydration appeared adequately restored he passed very little urine, and a measured 24-hour specimen consisted of $1 \mathrm{oz}$. only.

Investigations bearing on renal function are shown in Table 1.

TABLE 1

Serum and Urinary findings Bearing on Renal function

\begin{tabular}{|c|c|c|}
\hline & $\begin{array}{c}\text { October 25, } \\
1951\end{array}$ & $\begin{array}{c}\text { October 26, } \\
1951\end{array}$ \\
\hline Blood urea (mg. per $100 \mathrm{ml}$.) .. & 900 & 782 \\
\hline 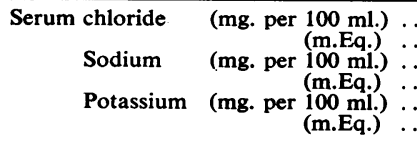 & $\begin{array}{cc}59 & \\
- & 103 \\
16 \cdot 3 & - \\
& 4 \cdot 2\end{array}$ & $\begin{array}{rr}318 & \\
341 & 91 \\
22 \cdot 7 & 148 \\
& 5 \cdot 8\end{array}$ \\
\hline $\begin{array}{l}\text { Urinary chloride (mg. per } 100 \mathrm{ml} \text { ) } \\
\text { Urea + ammonia (mg. per } 100 \mathrm{ml} \text {.) }\end{array}$ & 二 & $\begin{array}{r}78 \\
1,040\end{array}$ \\
\hline $\begin{array}{c}\text { Urine/plasma ratio: } \\
\\
\text { Urea }\end{array}$ & 二 & $\begin{array}{l}0.24 \\
1.3\end{array}$ \\
\hline $\begin{array}{ll}\text { Serum Albumin } & \text { (g. per } 100 \mathrm{ml} \text { ) } \\
\text { Protein } & \text { (g. per } 100 \mathrm{ml} \text {.) }\end{array}$ & $4 \cdot 6$ & -6.5 \\
\hline Urinary protein $\quad(\mathrm{mg}$. per $100 \mathrm{ml}$.). & - & 60 \\
\hline
\end{tabular}

* - = not estimated. Urinary estimations made on 24-hour specimen $(30 \mathrm{ml}$.)

The child's condition became progressively worse and the cyanotic attacks more frequent, and he died on the evening of October 26 at the age of 8 days.

The clinical diagnosis was uraemia probably due to some congenital abnormality of the kidneys, sclerema, and possibly a congenital cardiac defect.

\section{Necropsy Report}

A necropsy was carried out on the following morning, October 27, by Dr. D. G. F. Harriman.

There was no excess fluid in any of the body cavities. There was no congenital abnormality in the heart and the origins of the great vessels and of the coronary arteries were normal. Both lungs were oedematous and congested, with small areas of consolidation suggestive of atelectasis. The liver, spleen, pancreas and alimentary tract appeared entirely normal. Both kidneys were structurally normal, with foetal lobulation; the cortex and medulla were distinct and of normal width. The pelvis and ureter on both sides were normal, not dilated, and communicated with the bladder. The bladder contained no urine and was not dilated.
Histology. A histological examination gave the following information.

In the heart there was moderate glycogen vacuolation of muscle; there were no changes suggestive of elastosis.

Massive oedema and haemorrhage were seen in all sections of the lungs, but no signs of pneumonia. Some bronchioles contained extremely eosinophilic material (fibrin) without any surrounding inflammation.

In the liver mid-zonal vacuolation of many cells was seen.

A small number of acini of the pancreas were dilated with flattened cells and inspissated material in the lumen.

The neonatal zone of the suprarenal was small, showing early necrosis.

Sections taken from several regions in both kidneys revealed a normally formed cortex. Nephrogenesis was complete and no glomeruli could be found showing any degree of sclerosis. There was general vascular congestion, and some blood was present in collecting tubules without any epithelial reaction. Occasional vacuolation of tubular lining cells was present. The pelvis showed no inflammatory change.

The thymus showed early atrophy, with an increase in Hassal's corpuscles and gross depletion of lymphocytes in the cortex.

The epithelium was normal. It was unfortunately impossible to take a section from the areas showing clinical sclerema.

\section{Discussion}

From the findings at necropsy it is obvious that the clinical diagnosis was false, both insofar as there was no anatomical abnormality of the urinary tract, and that the heart also was normal.

Two possible causes of the extreme azotaemia remain; either the whole picture is one of extrarenal azotaemia developing in extra-uterine life, or there was in fact a functional abnormality of the kidneys not accompanied by any histological changes.

The facies of this infant so closely resembled that described by Potter (1946) and others in renal agenesis and renal hypoplasia, that it is tempting to consider the theory that this infant had gross functional renal failure of foetal origin. If the infant had been born with a normal blood urea level it is difficult to explain how, even with complete failure of all renal excretion, the blood urea could have risen to such an extent in the course of eight days. If no urine had been formed all the urea produced in the eight days of life must have accumulated in the body fluids. (In the present case there was actually a slight urinary secretion.) From the data of Barlow and McCance (1948) on the excretion of urea in the normal neonate, it can be calculated that in the first eight days of life approximately $510 \mathrm{mg}$. $/ \mathrm{kg}$. of body weight of urea would have been 
retained. If this had been evenly distributed in the body fluids, which represent about $70 \%$ of the body weight of the full term newborn infant (Widdowson and Spray, 1951), it would have represented a rise of about $73 \mathrm{mg}$. per $100 \mathrm{ml}$. body water, and a rise in blood urea concentration of $58 \mathrm{mg}$. per $100 \mathrm{ml}$. blood. This, if added to the maximum blood urea level found by McCance and Widdowson (1947) on the eighth day of life in infants with normal kidneys, i.e. $25 \mathrm{mg}$. per $100 \mathrm{ml}$., would give an approximate level of $80-85 \mathrm{mg}$. urea per $100 \mathrm{ml}$. blood, which is very considerably lower than that found in the present case.

It is generally accepted that urea excretion in the foetus is by the placenta, and that the survival of the foetus to full term with complete absence of any kidney tissue is thus made possible. Considerable experimental proof of this placental function has been summarized by Needham (1931) and further evidence was provided by Naeslund (1931). Unfortunately no pathological examination of the placenta of this case was possible.

These workers were dealing with normal infants born of normal mothers, and it is at least theoretically possible that if there is interference with kidney function in either mother or foetus, the latter might be born with a raised blood urea level. Because of the resemblance of our case, in outward appearance at least, to those of bilateral renal agenesis, a search was made in the literature for any record of the blood urea levels of infants born with this abnormality. Although there are now a large number of such cases on record, estimated by Leffler (1951) to reach a total of 163 , we have been quite unable to find any in which the blood urea level was estimated. This is largely because most of the cases were diagnosed at necropsy, but even in cases living for a few hours or days no estimation of blood urea levels seems to have been made. Potter (1952) states that post-mortem estimation of blood urea levels showed only moderate elevation, but none of the infants had lived longer than 11 hours.

Unfortunately, as already stated, we have been unable to obtain any information about the mother's health in pregnancy in this case, but it is unlikely that she can have had any severe degree of renal failure. Schofield (1950) compared a group of infants born of toxaemic mothers with a similar group of non-toxaemic mothers, and found a consistently higher level in the toxaemic group but the highest actual level was $119 \mathrm{mg} \%$ (Bevis, 1952).

It is impossible, therefore, to eliminate an intrinsic functional disturbance of tubules and glomeruli as the cause of uraemia in this infant, but equally impossible to state definitely that such a disturbance did in fact exist.

Extra-renal azotaemia is not uncommon in infants and young children from a variety of causes. The commonest cause is dehydration resulting from severe diarrhoea or vomiting or both. Uraemia results in these infants from a combination of haemodynamic factors (reduction in blood volume, increase in colloid osmotic pressure) and general dehydration as a result of which there is insufficient water available for urine formation. Doxiadis (1948) studied 47 infants with blood urea levels between 50 and $500 \mathrm{mg} . \%$, the azotaemia resulting from a variety of dehydrating illnesses, and discusses the mechanisms involved. Both he and Bell (1946) emphasize that if oliguria or anuria persist a stage is reached where the renal function is irreversibly affected, and even the restoration of adequate hydration will not produce a return to normal function. This may occur without any histological evidence of tubular damage.

In our case there was no diarrhoea and the vomiting was never severe, nor was the degree of dehydration on admission more than moderate.

Renal function is also controlled both by the posterior lobe of the pituitary and the adrenal cortex. It is doubtful whether either influence could produce such azotaemia in so short a time, but it is of interest to note that the serum chloride level fell and the serum potassium level rose in the 24-hour interval between the taking of the first and second specimens, which might be indicative of failure of adrenal cortical function. It would be unwise however to lay too much stress on these results alone, and in any event adrenal failure might well be secondary to the general metabolic disturbance.

There remains the possible effect of sclerema on renal function. We have been unable to find any record of the blood urea levels in cases of sclerema. Hughes and Hammond (1948) review the literature on this condition extensively and come to the conclusion that the hardening of fat in the subcutaneous tissues results from severe impairment of the peripheral circulation and shock. Dehydration may be partly masked by the induration of the skin. It seems quite possible that at least some degree of renal failure may result from this peripheral circulatory failure. It was unfortunate that, in our case, the limited necropsy made it impossible to obtain a specimen of the clinically sclerematous skin, but there was little doubt of the existence of the condition. 


\section{Summary}

A case is described of a newborn infant dying on the eighth day of life in extreme uraemia, with widespread sclerema neonatorum and abnormal facies. There was no demonstrable abnormality in the kidneys at necropsy.

The possible aetiology of the azotaemia is discussed.

We are indebted to Professor F. M. B. Allen and many of our colleagues at the Royal Belfast Hospital for Sick Children for much helpful discussion, to Professor R. A. McCance for his interest and advice, and to Dr. D. G. F.
Harriman, Department of Pathology, Queen's University, Belfast, for the pathological report. The photographs were taken by Mr. D. Mehaffey.

\section{REFERFNCES}

Barlow, A. and McCance, R. A. (1948). 'Archives of Disease in Childhood, 23, 225.

Bell, E. T. (1946). Renal Diseases, p. 405. Philadelphia.

Bevis, D. C. A. (1952). Personal Communication.

Doxiadis, S. A. (1948). Archives of Disease in Childhood, 23, 50.

Hughes, W. E. and Hammond, M. L. (1948). J. Pediat., 32, 676.

Leffer, R. J. (1951). Amer. J. clin. Path., 21, 752.

McCance, R. A. and Widdowson, E. M. (1947). Lancet, 1, 787.

McCance, R. A. and Widdowson, E. M. (1947), Lancet, 1, 787.
Naeslund, J. (1931). Acta. obstet. gynec. scand., 11, 474.

Needham, J. (1931). Chemical Embryology, vol. 3, p. 1515 Cambridge.

Potter, E. L. (1946). J. Pediat., 29, 68.

(1952). Persona! Communication.

Schofield, S. F. (1950). Archives of Disease in Childhood, 25, 207.

Widdowson, E. M. and Spray, C. M. (1951). Ibid. 26, 205.

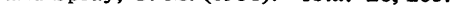

